\title{
North Indian Ocean warming and sea level rise in an OGCM
}

\author{
Bijoy Thompson, C Gnanaseelan*, Anant Parekh and P S Salvekar \\ Indian Institute of Tropical Meteorology, Pashan, Pune 411 008, India. \\ *e-mail: seelan@tropmet.res.in
}

The variability in the long-term temperature and sea level over the north Indian Ocean during the period 1958-2000 has been investigated using an Ocean General Circulation Model, Modular Ocean Model version 4. The model simulated fields are compared with the sea level observations from tide-gauges, Topex/Poseidon $(\mathrm{T} / \mathrm{P})$ satellite, in situ temperature profile observations from WHOI moored buoy and sea surface temperature (SST) observations from DS1, DS3 and DS4 moored buoys. It is seen that the long (6-8 years) warming episodes in the SST over the north Indian Ocean are followed by short episodes (2-3 years) of cooling. The model temperature and sea level anomaly over the north Indian Ocean show an increasing trend in the study period. The model thermocline heat content per unit area shows a linear increasing trend (from 1958-2000) at the rate of $0.0018 \times 10^{11} \mathrm{~J} / \mathrm{m}^{2}$ per year for north Indian Ocean. North Indian Ocean sea level anomaly (thermosteric component) also shows a linear increasing trend of $0.31 \mathrm{~mm} /$ year during $1958-2000$.

\section{Introduction}

The oceans largely remain a data-sparse region despite their importance in modifying the weather and climate. Even though atmospheric data over the oceans are also sparse (as compared to land), it has improved in recent years with the advent of satellite observations. Though remote sensing techniques can only measure a few surface oceanic variables such as sea surface temperature (SST) and sea surface height, the relative abundance of atmospheric data can be imposed in a state-ofthe-art Ocean General Circulation Model (OGCM) framework and more realistic simulation of oceanic geophysical parameters can be obtained in surface and subsurface of the oceans. In this scenario three dimensional OGCMs provide the most reliable estimate of variables in the surface and interior of oceans. The availability of high performance computing systems gave the model developers the freedom to reduce unrealistic approximations and employ more realistic parameterizations of unresolved processes. This in fact has helped to reduce the inaccuracies in the model simulations to a great extent (Griffies et al 2003).

Oceans are a major component of the global climate; covering roughly $72 \%$ of the planet's surface, they have thermal inertia and heat capacity to help maintain and restructure climate variability. Recent observations of global ocean temperature changes have shown substantial warming in the upper $1000 \mathrm{~m}$, averaging about $0.1^{\circ} \mathrm{C}$ between 1955 and 1995 (Levitus et al 2000). However the warming rate varies considerably among different ocean basins. Levitus et al (2001) suggested that the observed increase in ocean heat content is largely due to the increase of anthropogenic gases in earth's atmosphere. One of the immediate responses of ocean warming is the increase in sea level. The sea level rise can be contributed by various factors such as changes in thermal and haline structure of the oceans (steric change), melting of continental ice and filling of continental reservoirs (mass change), and geological changes due to the

Keywords. Ocean model; MOM4p0; Indian Ocean; ocean warming; sea level anomaly; oceanography; modelling; climate; atmospheric sciences. 
vertical crustal movement of tide gauges (Carton et al 2005). The thermosteric term is known to be a significant contributor to the global average sea level rise at a rate of $0.42 \pm 0.12 \mathrm{~mm} /$ year (during 1961-2003, Bindoff et al 2007). According to them the global average sea level rose at an average rate of $1.8 \mathrm{~mm} /$ year over 1961-2003. The other terms contributing to the sea level rise are melting of ice caps and ice sheets (glaciers and ice cap $\sim 0.5 \mathrm{~mm} /$ year, Greenland ice sheet $\sim 0.19 \mathrm{~mm}$ /year) and individual climatic contributions $(\sim 1.1 \mathrm{~mm} /$ year $)$. Meanwhile, the rate of sea level rise was faster over the period 1993-2003. Satellite altimetry shows that the global sea level rose at a rate of $3.1 \pm 0.7 \mathrm{~mm} /$ year over this period (Bindoff et al 2007). The linear increasing trend in the global sea level from 1950 are reported by many authors (Antonov et al 2002; Church et al 2004, 2006).

The above factors motivated us to carry out the present study on ocean thermal structure, heat content and sea level using a regional ocean model forced with interannually varying surface forcing. The model simulations are compared with in situ temperature and sea level anomaly (SLA) derived from satellite and tide gauges. The warming and sea level variability over the north Indian Ocean (NIO) during the period 1958-2000 is examined in the present study. The temperature and sea level variability over Arabian Sea (AS), Bay of Bengal (BoB) and Equatorial Indian Ocean (EIO) are discussed in detail.

\section{Model and methodology}

The OGCM used for this study is the Geophysical Fluid Dynamics Laboratory (GFDL) Modular Ocean Model Version 4 (MOM4p0) (Griffies et al 2003). MOM4p0 is a $\mathrm{z}$-coordinate (3 dimensional) numerical representation of hydrostatic primitive equations with Boussinesq approximation and explicit free surface. Prognostic variables include the two active tracers of temperature and salinity, the horizontal velocity components and passive tracer field, the height of free ocean surface. The time stepping scheme is based on a predictorcorrector method, which is more stable than the leapfrog scheme. The model tracer field, the baroclinic velocity and free surface height are computed every 9600 seconds. Since the tracer and baroclinic time steps are equal, total tracer is conserved in the model, except for time discretisation errors arising from the use of a time filtered surface height. The barotropic fields have a time step of 120 seconds. The equation of state is based on the formulation described by McDougall et al (2003), which is more accurate than the linearised equation of state. The vertical mixing in the model is handled through the K-Profile Parameterisation Scheme (Large et al 1994) using local and non-local mixing with BryanLewis Background Diffusivity (Bryan and Lewis 1979). The heating due to penetrative shortwave radiation is attenuated by the inclusion of chlorophyll data.

The model region is $30^{\circ} \mathrm{E}$ to $120^{\circ} \mathrm{E}$ and $40^{\circ} \mathrm{S}$ to $25^{\circ} \mathrm{N}$ with 30 vertical levels. The upper ocean mixed layer and thermocline zones are well resolved in the model with 15 vertical levels within a depth of $150 \mathrm{~m}$. The vertical resolution gradually changes from $10 \mathrm{~m}$ to a maximum of $712 \mathrm{~m}$ at $5600 \mathrm{~m}$. The model has been provided with a realistic topography of $0.5^{\circ}$ resolution. Model has a constant zonal resolution of $1^{\circ}$ and meridional resolution varying from $0.3353^{\circ}$ at equator to $0.7^{\circ}$ at $25^{\circ} \mathrm{N}$ and $1.5^{\circ}$ at $40^{\circ} \mathrm{S}$. Solid walls are assumed at the eastern and southern boundaries and no slip conditions are assumed for momentum. For temperature and salt no flux boundary conditions are assumed. Additionally, the southern and eastern boundaries are provided with a sponge layer of $4^{\circ}$ width, where the temperature and salinity are restored to monthly climatologies of Levitus (1998) with a time-scale of 5 days. The model was initialized with annual climatologies of temperature and salinity from Levitus (1998) and forced by climatological downwelling shortwave and longwave radiation, $10 \mathrm{~m}$ surface wind fields, specific humidity, air temperature, surface pressure and surface precipitation from NCAR climatology (Large and Yeager 2004). Chlorophyll-a climatology computed from SeaWiFS satellite for the period 1999-2001 is used for the shortwave penetration scheme. After 20 years of spin up, the model has been integrated from 1958-2000 with NCAR corrected interannual datasets (Large and Yeager 2004) of daily downwelling shortwave and longwave radiation, 6 -hourly $10 \mathrm{~m}$ surface wind fields, specific humidity, air temperature, surface pressure and monthly precipitation.

\section{Data used}

The in situ data used for the model validation are the Woods Hole Oceanographic Institution (WHOI) mooring observations at $61.5^{\circ} \mathrm{E}$, $15.5^{\circ} \mathrm{N}$ from 15 October, 1994 to 20 October, 1995 , National Institute of Ocean Technology (NIOT) moorings DS1 at $69.3^{\circ} \mathrm{E}, 15.3^{\circ} \mathrm{N}$ from 1 February, 1998 to 31 December, $1998, \mathrm{DS} 3$ at $87^{\circ} \mathrm{E}, 13^{\circ} \mathrm{N}$ from 1 January, 1998 to 10 June, 1998 and DS4 at $89^{\circ} \mathrm{E}, 19^{\circ} \mathrm{N}$ from 1 January, 1998 to 31 December, 1998. The temperature observations at the surface and subsurface down to $250 \mathrm{~m}$ observed from WHOI mooring are used for comparison 


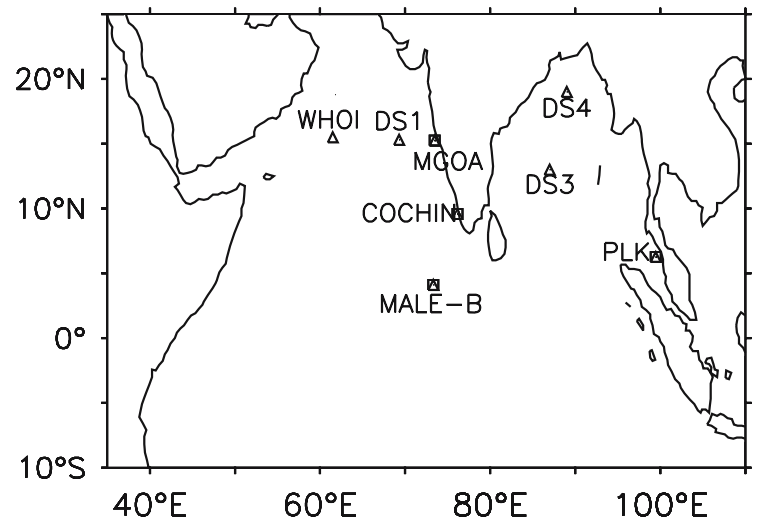

Figure 1. Map showing the location of mooring buoys WHOI, DS1, DS3, DS4 and tide-gauges at Mormugao (MGOA), Cochin, Male-B and Palau Langkawi (PLK).

with model simulations. The details of instruments and observations used in the WHOI moorings are discussed in Weller et al (1998, 2002). The SST measured from DS1, DS3 and DS4 buoys are also compared with model SST. The accuracy of the DS1, DS3 and DS4 buoy data were discussed in Premkumar et al (2000). The temperature in the first layer $(0-5 \mathrm{~m})$ of the model is taken as the model SST and the temperature observations are averaged in the same layer to obtain the observed SST.

The $\mathrm{T} / \mathrm{P}$ altimeter provides sea surface height with a repeat cycle of 10 days with the accuracy of approximately $2 \mathrm{~cm}$ (Cheney et al 1994; Tapley et al 1994). The SLA derived from $\mathrm{T} / \mathrm{P}$ observations are extensively used for studying interannual sea level variations in the Indian Ocean (Chambers et al 1999; Vinayachandran et al 1999). The SLA from $\mathrm{T} / \mathrm{P}$ is averaged monthly for the period 1993-2000 and compared to model SLA. The tide-gauge observations of mean monthly sea level from the data archive of Permanent Service for Mean Sea Level (Woodworth and Player 2003) are used for the comparison of model sea level. The Revised Local Reference (RLR) data are analysed here. In the north Indian Ocean (north of $10^{\circ} \mathrm{S}$ ) not many island tide-gauge observations are available, also the time period of observations is shorter. Meanwhile the coastal tide-gauges provide sea level observations of longer record length. Unnikrishnan et al (2006) and Unnikrishnan and Shankar (2007) used tide-gauge observations along the Indian coast for studying the sea level changes over the region. Unnikrishnan et al (2006) found mean sea level rise of less than $1 \mathrm{~mm} /$ year at selected stations along the coast of India, whereas Unnikrishnan and Shankar (2007) did vertical land movement corrections on the data and found a rise of about $1.29 \mathrm{~mm} /$ year. The coastal tide-gauge observations from Mormugao $\left(73.48^{\circ} \mathrm{E}, 15.25^{\circ} \mathrm{N}\right.$,
Table 1. The correlation and rms difference of SST between model and moored observations.

\begin{tabular}{lccc}
\hline Mooring & Location & Correlation & $\begin{array}{c}\text { rms } \\
\text { difference }\left({ }^{\circ} \mathrm{C}\right)\end{array}$ \\
\hline WHOI & $15.5^{\circ} \mathrm{N}, 61.5^{\circ} \mathrm{E}$ & 0.95 & 0.45 \\
DS1 & $15.3^{\circ} \mathrm{N}, 69.3^{\circ} \mathrm{E}$ & 0.94 & 0.29 \\
DS3 & $87^{\circ} \mathrm{E}, 13^{\circ} \mathrm{N}$ & 0.96 & 0.4 \\
DS4 & $89^{\circ} \mathrm{E}, 19^{\circ} \mathrm{N}$ & 0.95 & 0.56 \\
\hline
\end{tabular}

1969-2000), Cochin $\left(76.16^{\circ} \mathrm{E}, 9.8^{\circ} \mathrm{N}, 1958-2000\right)$, Palau Langkawi $\left(99.46^{\circ} \mathrm{E}, 6.26^{\circ} \mathrm{N}, 1986-2000\right)$ and island tide-gauge observation from Male-B (Hulule) $\left(73.32^{\circ} \mathrm{E}, 4.11^{\circ} \mathrm{N}, 1991-2000\right)$ are compared with model SLA. The model SLA is averaged in a $2^{\circ} \times 2^{\circ}$ box over the observation point. The locations of the mooring and tide-gauge observations used in the study are shown in figure 1.

HadISST v.1.1 and the Simple Ocean Data Assimilation (version SODA_1.4.2) dataset are also used for the model calibration and analysis of model simulated temperature fields. In situ sea surface observations and satellite estimates at the sea surface are included in the HadISST Global Ocean Surface Temperature analysis (Rayner et al 2003). SODA is a University of Maryland reanalysis product using an eddy-permitting global model based initially on POP $\_1.3$ numerics and SODA procedure (Carton et al 2005; Carton and Giese 2006).

\section{Results and discussions}

\subsection{Model temperature - validation}

The model temperature simulations are validated with the in situ observations before doing a detailed analysis on its variability. The continuous mooring observations by WHOI, DS1, DS3 and DS4 buoys provided an opportunity for the validation of model simulated temperature. The correlation and rms difference between model and in situ observations are given in table 1 . Figure 2(a) shows the time series of daily SST from model and WHOI mooring off the coast of Oman $\left(61.5^{\circ} \mathrm{E}\right.$, $\left.15.5^{\circ} \mathrm{N}\right)$. The rms difference between WHOI and model SST is $0.45^{\circ} \mathrm{C}$. The SST variability is very well correlated (correlation coefficient $=0.95$ ) with the observed variability. Cooling of the AS in the boreal winter (January-February) and during monsoon (July-August) seasons and warming in pre-monsoon (May) and post-monsoon (October) are well reproduced by the model. Maximum difference $\left(\sim 1^{\circ} \mathrm{C}\right)$ between model and observations is seen during July-August, where the model underestimated the SST cooling. The vertical section of 

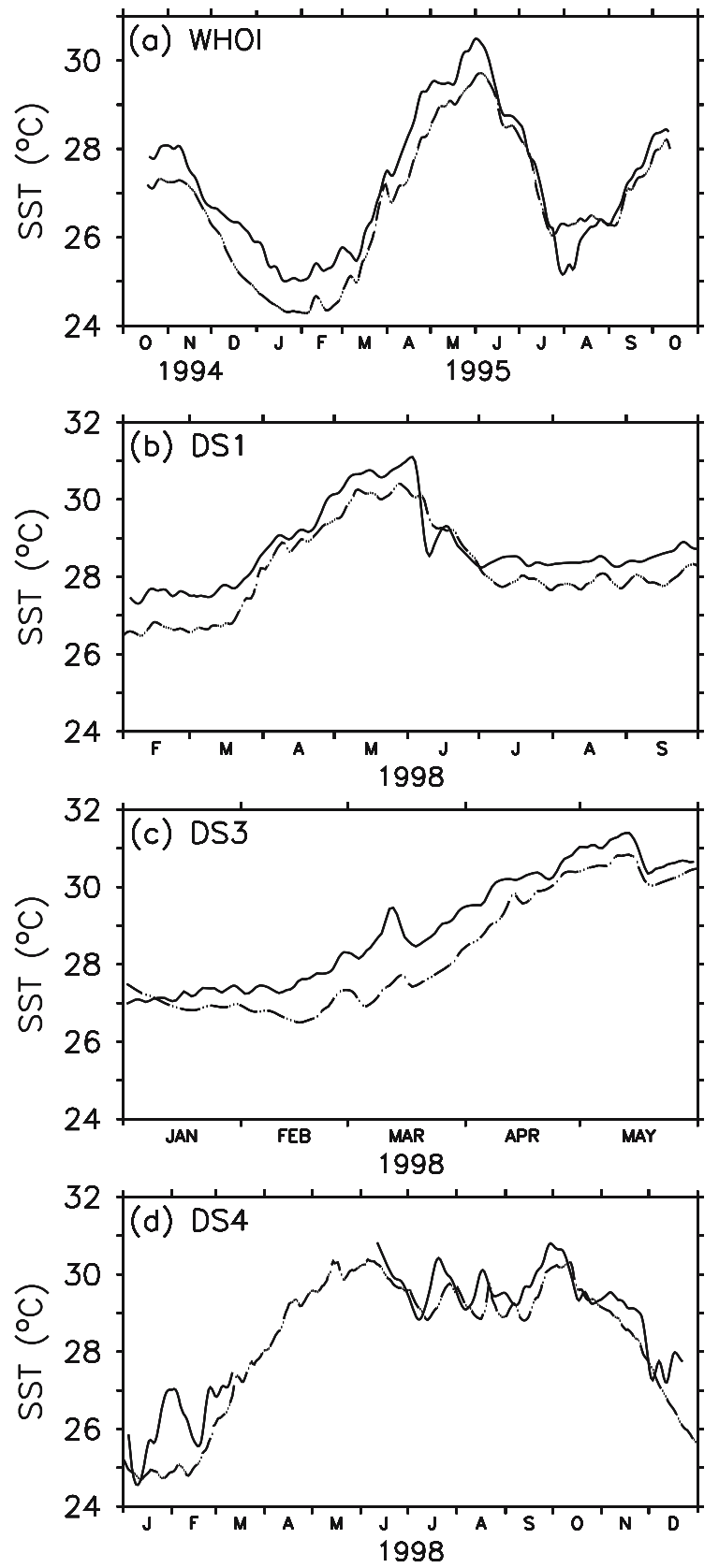

Figure 2. The SST comparison from mooring observation (continuous line) (a) WHOI $\left(61.5^{\circ} \mathrm{E}, 15.5^{\circ} \mathrm{N}\right)$, (b) DS1 $\left(69.3^{\circ} \mathrm{E}, 15.3^{\circ} \mathrm{N}\right),(\mathbf{c}) \operatorname{DS} 3\left(87^{\circ} \mathrm{E}, 13^{\circ} \mathrm{N}\right)$ and (d) DS4 $\left(89^{\circ} \mathrm{E}\right.$, $\left.19^{\circ} \mathrm{N}\right)$. The model SST corresponding to the mooring locations is shown as dashed line.

temperature from WHOI and model at the mooring point is shown in figure 3 . It reveals that the convective cooling during winter season and pre-monsoon warming are well reproduced by the model. The vertical extent of pre-monsoon warming is slightly underestimated by the model. Also the monsoonal cooling (due to momentum flux and surface heat fluxes) is not well simulated by the model.

The model SST and DS1 buoy observation are compared in figure 2(b). As seen in figure 2(a), the cold bias in the model SST is observed in DS1 mooring location also. The DS1 buoy is located in the eastern $\mathrm{AS}$ region $\left(69.3^{\circ} \mathrm{E}, 15.3^{\circ} \mathrm{N}\right)$. The pre-monsoon warming and monsoon cooling of SST over this region is well reproduced by the model. The steep fall in SST seen in buoy observation in early June was due to the presence of a severe cyclonic storm in the AS during June 3-9 (Premkumar et al 2000). Such a steep fall is not seen in the model SST. This could be due to the inaccuracy and the coarseness of the forcing fields (i.e., wind and precipitation fields), since no well-marked cyclonic condition is seen in the forcing fields. The intermediate model resolution may also be a possible reason for this discrepancy. The SST comparison at DS3 and DS4 buoy locations is shown in figure 2(c) and 2(d). The DS3 and DS4 buoys are located in the central BoB. These areas are prone to intraseasonal oscillation (Sengupta and Ravichandran 2001). The time series at DS4 location (figure $2 \mathrm{~d}$ ) shows the intraseasonal oscillation in the observations during the summer monsoon, which is also reproduced by the model SST.

\subsection{Model sea level anomalies - validation}

The correlation between $\mathrm{T} / \mathrm{P}$ observed SLA and model SLA shows that the model is in good agreement with the observations (figure 4a) except over the western $\mathrm{BoB}$, western AS and eastern Indian Ocean south of $10^{\circ} \mathrm{S}$. Over $65 \%$ of the basin is found to have correlation above $95 \%$ confidence level. Correlation above 0.9 is seen in the southeastern AS. The correlation is observed to be above 0.80 in regions where strong interannual variability is observed (e.g., eastern EIO). The root mean square (rms) difference between model and $\mathrm{T} / \mathrm{P}$ anomalies is shown in figure 4(b). Over the tropical Indian Ocean region between $10^{\circ} \mathrm{S}$ and $10^{\circ} \mathrm{N}$, most of the AS and southern BoB, the rms differences are observed to be less than $4 \mathrm{~cm}$, which represents less than $35 \%$ of standard deviation of $\mathrm{T} / \mathrm{P}$ SLA (figure 4d). Inconsistency between model and $\mathrm{T} / \mathrm{P}$ SLA are seen in the western AS, western $\mathrm{BoB}$ and in the Indian Ocean south of $10^{\circ} \mathrm{S}$, where the correlation is also less.

The basin wide average of SLA for the period 1993 to 2000 over north Indian Ocean $\left(45^{\circ} \mathrm{E}\right.$ to $110^{\circ} \mathrm{E}, 10^{\circ} \mathrm{S}$ to $\left.25^{\circ} \mathrm{N}\right)$, Arabian Sea $\left(45^{\circ} \mathrm{E}\right.$ to $80^{\circ} \mathrm{E}$, $5^{\circ} \mathrm{N}$ to $\left.25^{\circ} \mathrm{N}\right)$, Bay of Bengal $\left(80^{\circ} \mathrm{E}\right.$ to $100^{\circ} \mathrm{E}, 5^{\circ} \mathrm{N}$ to $\left.20^{\circ} \mathrm{N}\right)$ and equatorial Indian Ocean $\left(40^{\circ} \mathrm{E}\right.$ to $110^{\circ} \mathrm{E}, 10^{\circ} \mathrm{S}$ to $\left.5^{\circ} \mathrm{N}\right)$ are drawn in figures $5(\mathrm{a})$, $5(\mathrm{~b}), 5(\mathrm{c})$ and $5(\mathrm{~d})$ respectively. It is important to note that the deseasonalised time series are shown. The seasonal signal was computed considering the 8 years average of each month and the difference between total and seasonal signal is considered as 

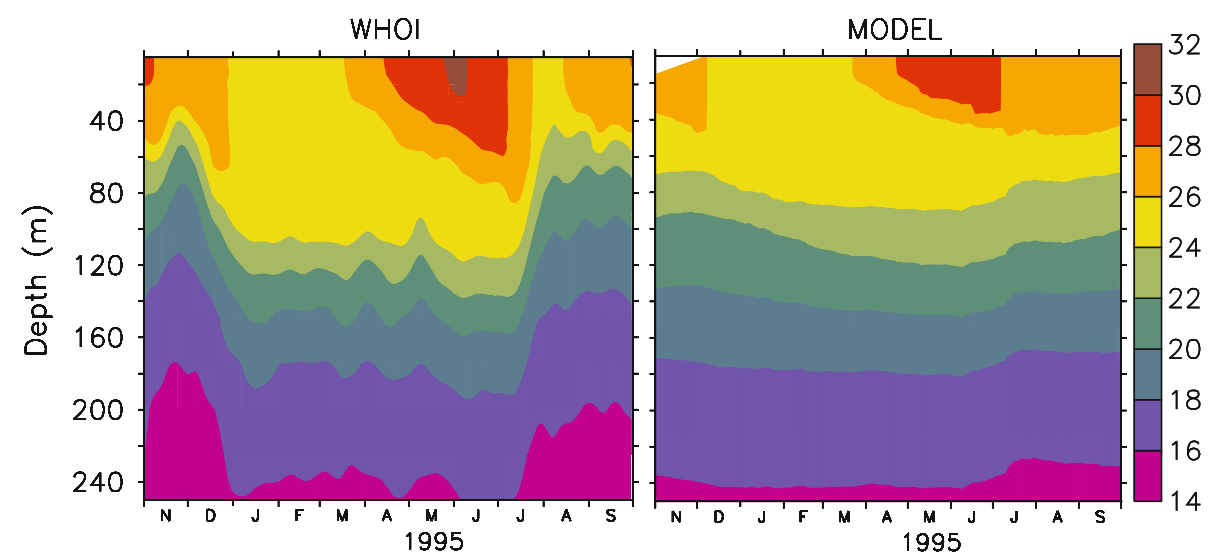

Figure 3. The vertical section of temperature at $61.5^{\circ} \mathrm{E}, 15.5^{\circ} \mathrm{N}$ from WHOI observation and model.

a) Correlation

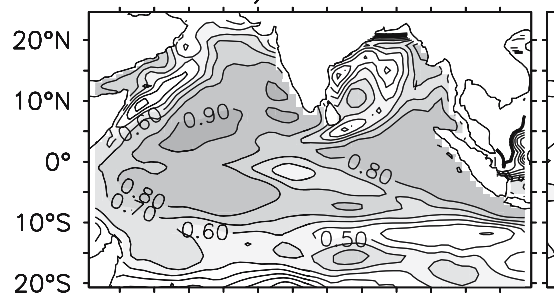

c) Std deviation Model

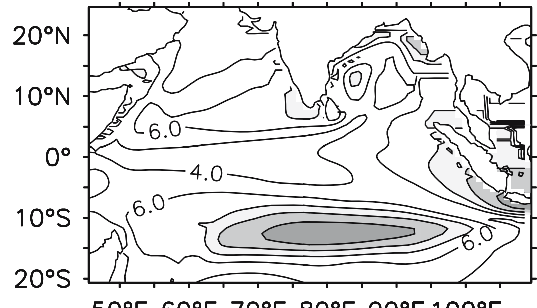

$50^{\circ} \mathrm{E} 60^{\circ} \mathrm{E} 70^{\circ} \mathrm{E} 80^{\circ} \mathrm{E} 90^{\circ} \mathrm{E} 100^{\circ} \mathrm{E}$ b) RMS difference

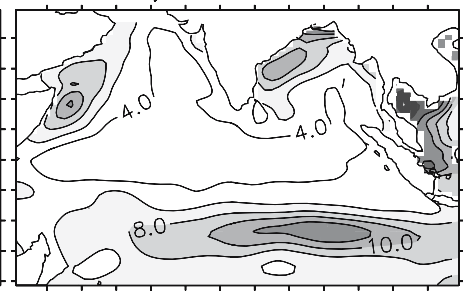

d) Std deviation TP

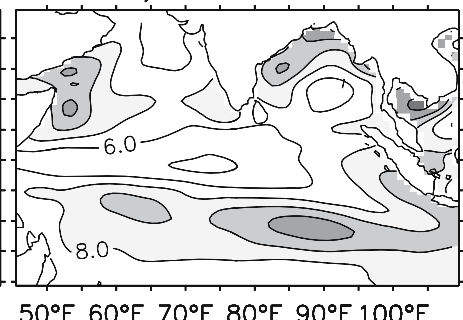

Figure 4. (a) The correlation between sea surface height anomalies from Topex and model (correlation above 0.5 shaded). (b) rms difference between sea surface height anomalies from Topex and model (rms difference above $6 \mathrm{~cm}$ shaded). (c) Model sea surface height anomaly standard deviation. (d) Topex surface height anomaly standard deviation. For figures $4(\mathrm{c})$ and $4(\mathrm{~d})$ standard deviation above $8 \mathrm{~cm}$ shaded.

the deseasonalised signal. The correlation and rms difference between model and T/P SLA observation is shown in table 2 . Over NIO the correlation of 0.6 is seen between model and $\mathrm{T} / \mathrm{P}$, while the rms difference is $0.78 \mathrm{~cm}$, which is less than $20 \%$ peak-to-peak variation in T/P SLA. Notable difference between the model SLA and observed SLA is seen in the $\mathrm{BoB}$ region. The rms difference is observed to be relatively higher $(1.9 \mathrm{~cm})$ in $\mathrm{BoB}$, which represents $15 \%$ of variability in T/P SLA.

The SLA from tide-gauge observations at Cochin, Mormugao, Male-B (Hulule) and Palau Langkawi are plotted against the model SLA in figure 6 . The time series are detrended by removing their linear trends. It is important to note that this exercise has been carried out for avoiding the correlation arising due to the trends. However, this has been done only for the validation of the model SLA. We have used the original data (without removing trends) for all the analysis. In these tide-gauges long period records are available only for Cochin and Mormugao. There are some long gaps in data available for the Mormugao station, from 1979-1986 and 1994-1998. The figure shows that good agreement is found between model and observations. The correlation between model and tide-gauge SLA are $0.71,0.71,0.78$ and 0.83 respectively.

\subsection{Warming trend in the north Indian Ocean and decadal variability of temperature and sea level}

The ocean heat content is a dominant component of the variability of earth heat balance (Rossby 1959; Levitus et al 2001). The ocean temperature 

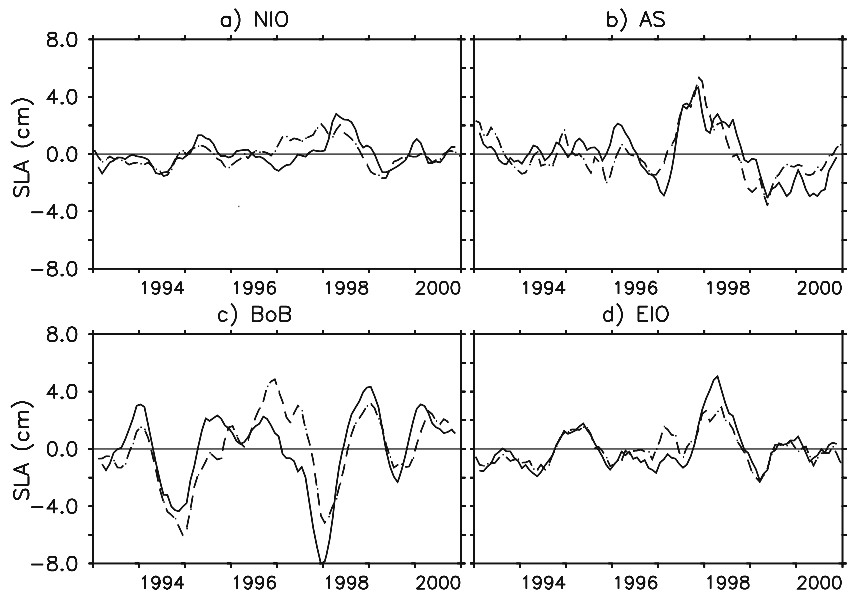

Figure 5. Deseasonalised sea level anomalies (in $\mathrm{cm}$ ) averaged over (a) Northern Indian Ocean $\left(45^{\circ} \mathrm{E}\right.$ to $110^{\circ} \mathrm{E}, 10^{\circ} \mathrm{S}$ to $\left.25^{\circ} \mathrm{N}\right)$, (b) Arabian Sea $\left(45^{\circ} \mathrm{E}\right.$ to $80^{\circ} \mathrm{E}, 5^{\circ} \mathrm{N}$ to $25^{\circ} \mathrm{N}$ ), (c) Bay of Bengal $\left(80^{\circ} \mathrm{E}\right.$ to $100^{\circ} \mathrm{E}, 5^{\circ} \mathrm{N}$ to $\left.20^{\circ} \mathrm{N}\right)$ and (d) Equatorial Indian Ocean $\left(40^{\circ} \mathrm{E}\right.$ to $110^{\circ} \mathrm{E}, 5^{\circ} \mathrm{N}$ to $\left.10^{\circ} \mathrm{S}\right)$. Continuous line represents Topex and dashed line represents model SLA.

Table 2. The correlation and rms difference of $S L A$ between model and $T / P$.

\begin{tabular}{lcc}
\hline Region & Correlation & $\begin{array}{c}\mathrm{rms} \\
\text { difference }(\mathrm{cm})\end{array}$ \\
\hline $\mathrm{NIO}$ & 0.6 & 0.78 \\
$\mathrm{AS}$ & 0.75 & 1.2 \\
$\mathrm{BoB}$ & 0.73 & 1.9 \\
$\mathrm{EIO}$ & 0.87 & 0.7 \\
\hline
\end{tabular}

variability in multi year/decadal time-scales is significant in this warming scenario. There are many studies available in the literature, which document the warming of the world oceans in recent decades (Levitus et al 2000 and 2005). The SST averaged over the NIO, AS, BoB and EIO from HadISST (observation), model and SODA are shown in figures $7(\mathrm{a}), 7(\mathrm{~b}), 7(\mathrm{c})$ and $7(\mathrm{~d})$ respectively. The model SST is seen to be $0.2-0.4^{\circ} \mathrm{C}$ higher than observations in all these basins. However, the SODA temperature is about $0.8-0.9^{\circ} \mathrm{C}$ greater than observations. The NIO shows a warming of about $0.4^{\circ} \mathrm{C}$ in the model SST as well as HadISST during the last 40 years. A similar pattern is also seen in SODA SST data. The warming tendency is clearly seen in the time series of SST averaged over the individual basins $\mathrm{AS}, \mathrm{BoB}$ and EIO (figure $7 b-d$ ). One interesting feature observed in the SST variability over NIO is the quasi-decadal time-scale oscillation. It is observed that the long warming episodes (6-8 years) are followed by short episodes (2-3 years) of SST cooling. A similar pattern of variability is seen in all the basins.

Warming is not only confined to the surface, the warming trend is observed well below
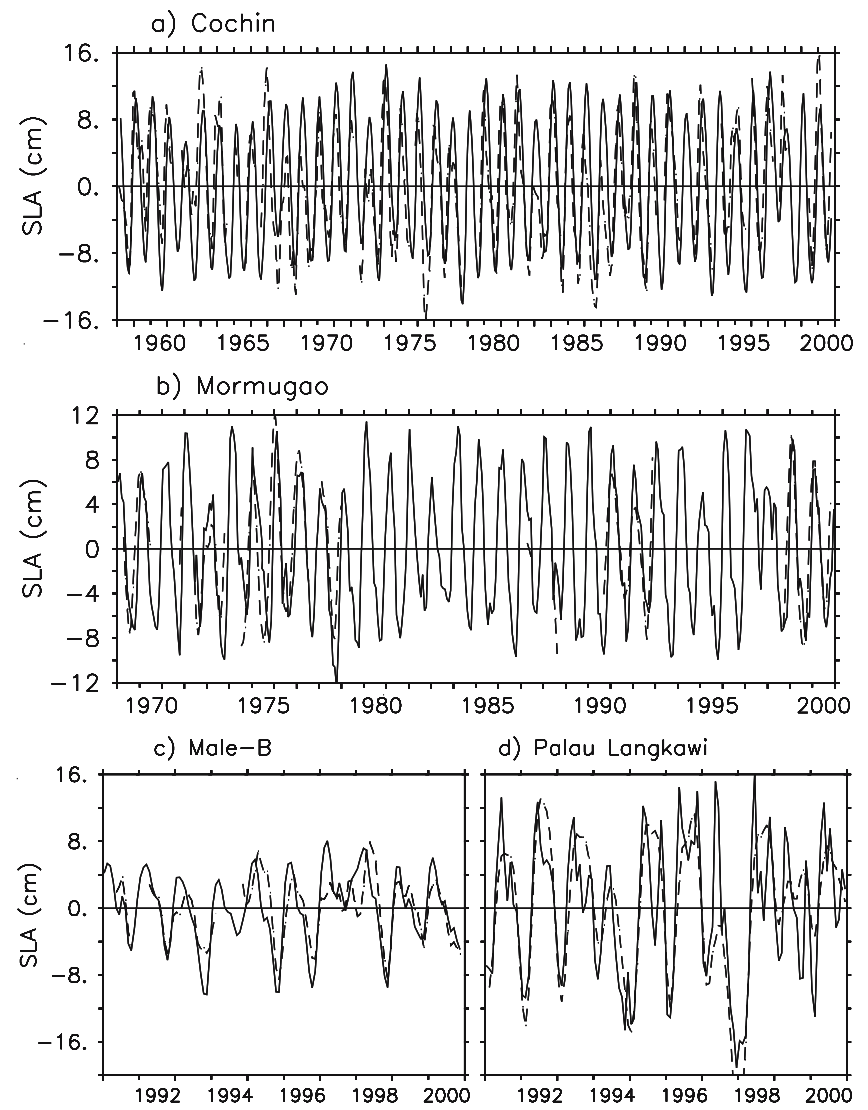

Figure 6. The time series of SLA from tide-gauge observations (dashed line) and model (continuous line) at (a) Cochin, (b) Mormugao, (c) Male and (d) Palu Langkawi. The time series are detrended by removing their linear trends.

the thermocline depth also. The depth of $20^{\circ} \mathrm{C}$ isotherm is taken as a proxy for tropical oceanic thermocline. The thermocline heat content is considered here as the present study focuses mainly on the upper ocean warming in the north Indian Ocean basin. Moreover, the picture is not much different when we take the upper $700 \mathrm{~m}$ and most of the warming tendency is represented by the upper $300 \mathrm{~m}$. The linear trend of thermocline heat content (HCd20) from 1958-2000 is illustrated in figure $8(\mathrm{a})$. The trend of $\mathrm{HCd} 20$ is not uniformly distributed in space. The highest positive trend is found in the AS north of $12^{\circ} \mathrm{N}$, western $\mathrm{BoB}$ and between equator and $5^{\circ} \mathrm{S}$. The negative linear trend seems to be concentrated over the Somali coast and the region south of $5^{\circ} \mathrm{S}$ and west of $80^{\circ} \mathrm{E}$. The $\mathrm{HCd} 20$ for unit area calculated for the $\mathrm{NIO}, \mathrm{AS}, \mathrm{BoB}$ and EIO regions are shown in figure 9. The linear trend line for the corresponding time series is also drawn in the figure. Similar to the SST warming observed in these basins, the $\mathrm{HCd} 20$ also showed an increasing trend. The $\mathrm{HCd} 20$ values in $\mathrm{AS}$ is higher than BoB and EIO basins. This is due to the existence of deeper thermocline in AS. The thermocline in the AS 

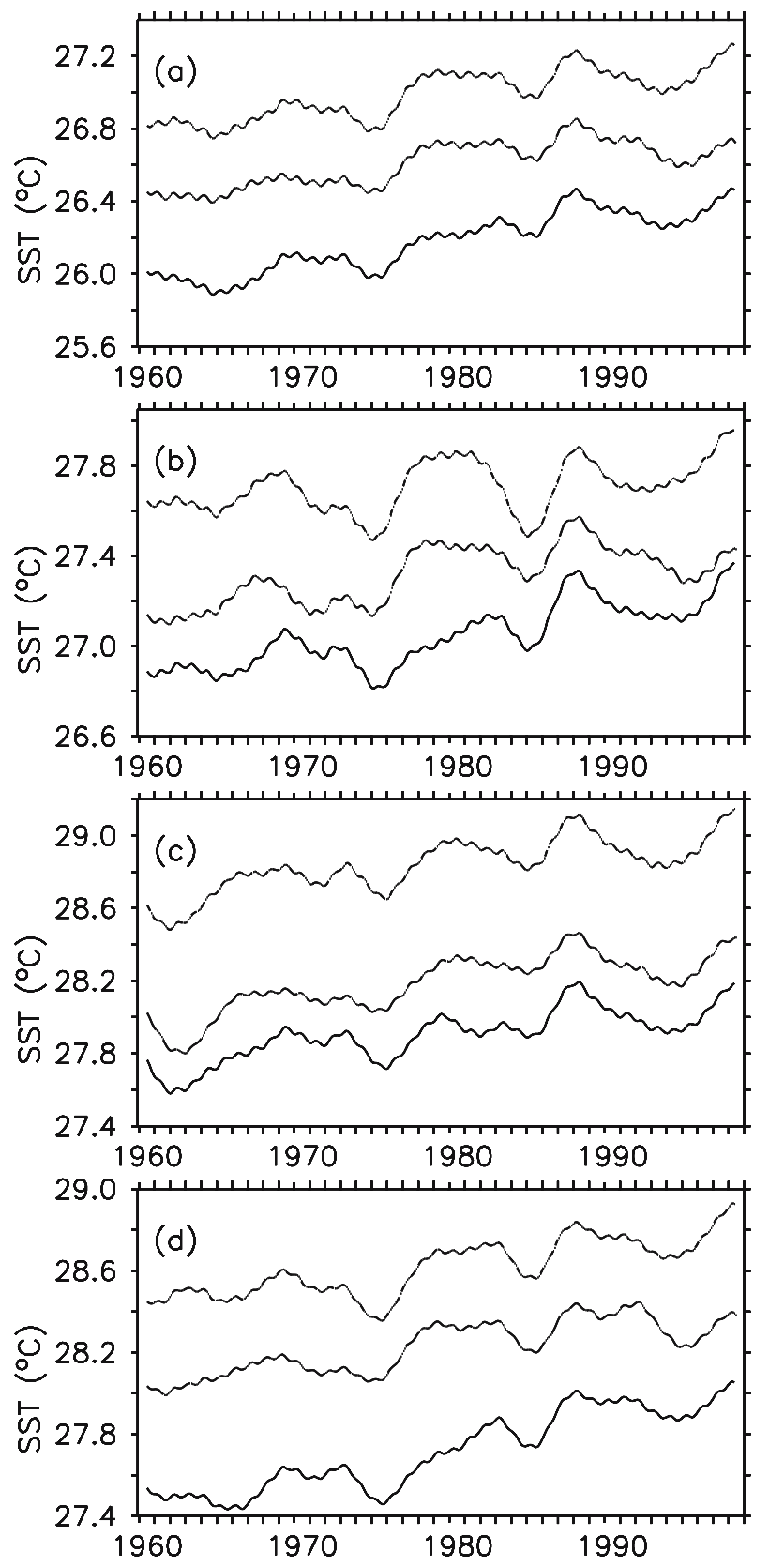

Figure 7. Sea surface temperature averaged over (a) north Indian Ocean, (b) Arabian Sea, (c) Bay of Bengal and (d) equatorial Indian Ocean. Continuous line represents Had ISST, dashed line represents model and dotted line denotes SODA. The time series low-pass filtered with a 5 -year running filter.

shows a deepening of $10 \mathrm{~m}$ (125 to $135 \mathrm{~m}$ ) in the last 40 years, meanwhile the BoB and EIO shows deepening of $10 \mathrm{~m}$ (105 to $115 \mathrm{~m})$ and $5 \mathrm{~m}$ (110 to $115 \mathrm{~m}$ ) respectively. The pattern of variability in the $20^{\circ} \mathrm{C}$ isothermal surface is also similar to that of $\mathrm{HCd} 20$ (figure not shown). For the NIO the linear trend of thermocline heat content increase (from 1958-2000) is $0.0018 \times 10^{11} \mathrm{~J} / \mathrm{m}^{2}$ per year, representing a heat content increase of $0.079 \times 10^{11} \mathrm{~J} / \mathrm{m}^{2}$. For $\mathrm{AS}, \mathrm{BoB}$ and EIO regions
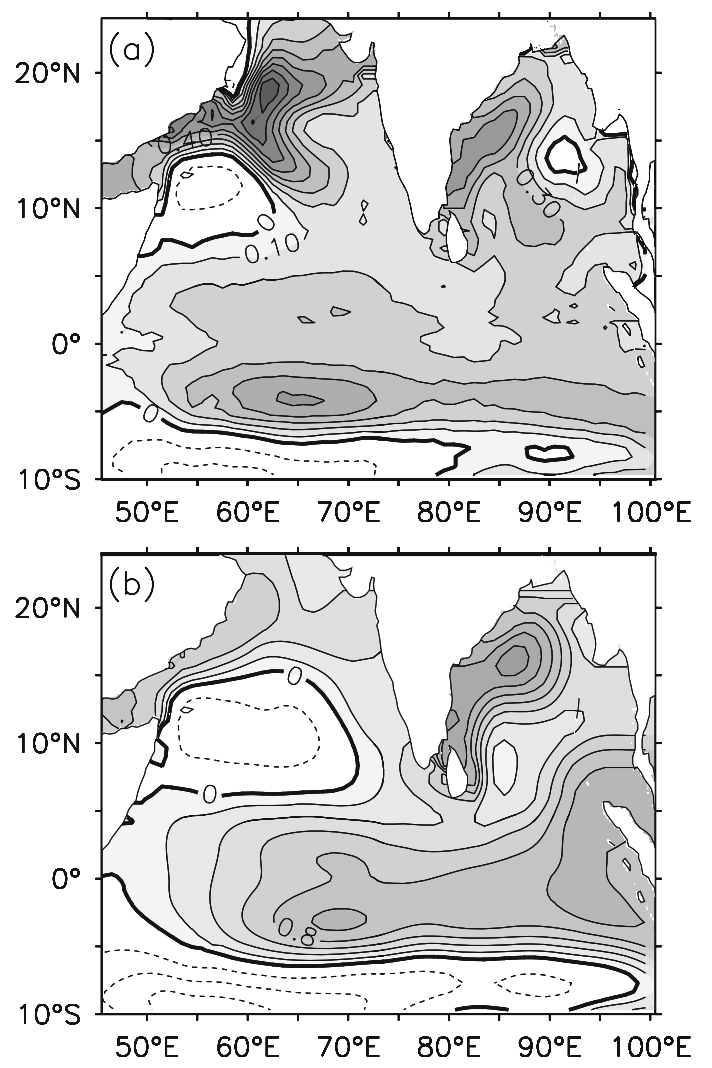

Figure 8. Linear trends for 1958-2000 (a) model thermocline heat content in $10^{9} \mathrm{~J} / \mathrm{m}^{2}$ per year and (b) model sea level anomaly in $\mathrm{mm}$ per year.

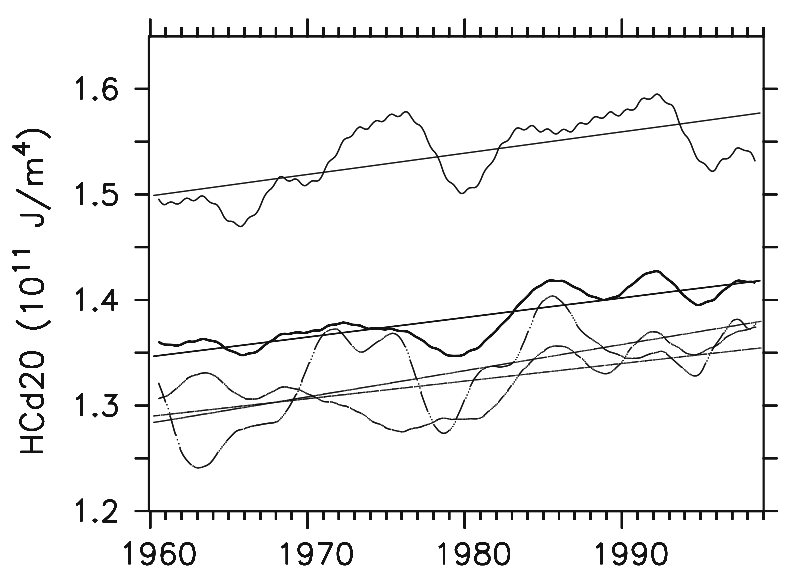

Figure 9. The thermocline heat content per unit area calculated from model for the north Indian Ocean (continuous thick line), Arabian Sea (continuous thin line), Bay of Bengal (dashed line) and equatorial Indian Ocean (dotted line). The corresponding linear trend of each time series is also shown. The time series low-pass filtered with a 5 -year running filter.

the rate of increase of heat content (linear trend) is $0.0020,0.0025$ and $0.0017 \times 10^{11} \mathrm{~J} / \mathrm{m}^{2}$ per year. The warming tendency is seen up to $300 \mathrm{~m}$ depth. The warming trend of the oceanic subsurface, even below the thermocline depth illustrates the role of ocean dynamics in the warming process. In the 


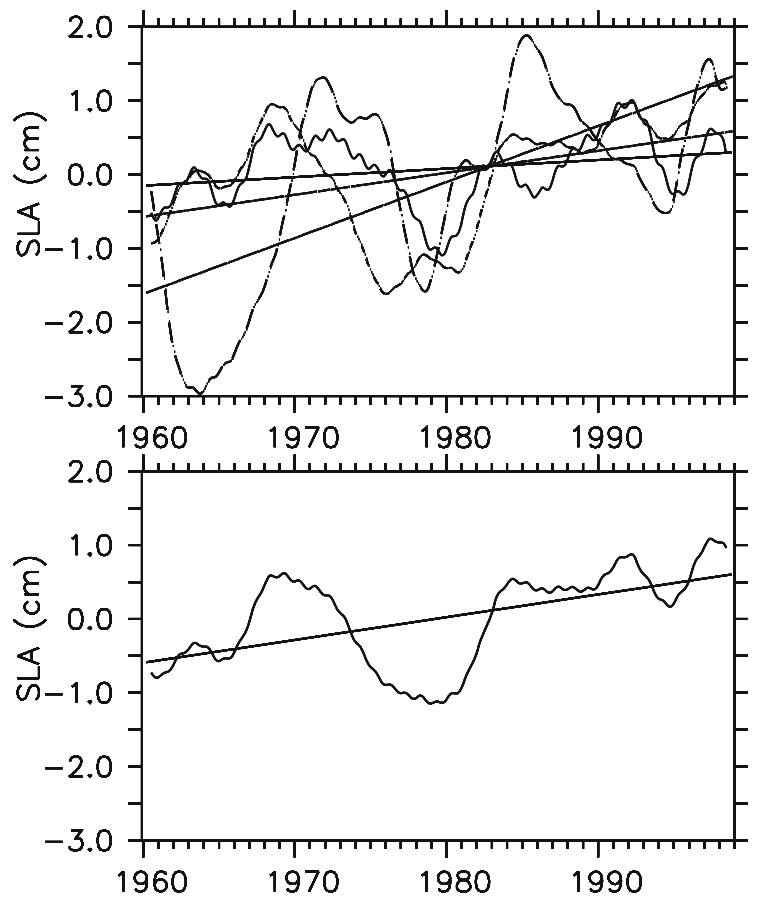

Figure 10. The SLA from model. In the top panel, Arabian Sea (continuous line), Bay of Bengal (dashed line), equatorial Indian Ocean (dotted line) and the bottom panel represents SLA over north Indian Ocean. The corresponding linear trend lines are also shown. The time series low-pass filtered with a 5-year running filter.

subsurface below $100 \mathrm{~m}$, the magnitude of warming slowly decreases and beyond $400 \mathrm{~m}$ slight cooling $\left(\sim 0.1^{\circ} \mathrm{C}\right)$ is seen in the model simulation (figure not shown).

Similar to the warming trend in temperature, the model SLA also shows an increasing trend in the NIO in the last four decades. The linear trend of model SLA is shown in figure $8(\mathrm{~b})$. The rise in sea level trend appears to be well related to the $\mathrm{HCd} 20$ trend over most of the regions. The correlation between these two is found to be 0.87 over the NIO. It highlights the contribution of thermosteric term in the sea level rise over NIO. The analysis of model SLA shows that in the NIO, the sea level rise is minimum in the $\mathrm{AS}$ and maximum in the $\mathrm{BoB}$ (figure 10). The SLA exhibits an increasing trend in the mid 1960s and late 1970s. In the NIO the SLA shows a linear increasing trend of $0.31 \mathrm{~mm} /$ year, which signify sea level rise of $13.22 \mathrm{~mm}$ during 1958-2000 (figure 10). Since the OGCM used for the study is closed in the eastern and southern boundaries, the possible contribution of melting of ice caps and ice sheets and other climatic contributions towards this sea level rise are not accounted. So the linear trend in the model SLA can be attributed by the thermosteric effect. The linear trend of model SLA $(0.31 \mathrm{~mm} /$ year $)$ is close to the observed global thermosteric contribution $(0.42 \pm 0.12 \mathrm{~mm} /$ year $)$. During $1993-2000$ the T/P observation shows a global average sea level rise of about $3 \mathrm{~mm} /$ year. However, the rate of sea level rise over the NIO is observed to be less than one third of global average sea level rise, showing a linear increasing trend of $0.96 \mathrm{~mm} /$ year. The model SLA over the period 1993-2000 shows a rise of $0.8 \mathrm{~mm} /$ year.

\section{Summary}

The ocean general circulation models form an integral part of the dynamical and thermodynamical process studies of the oceans. The models need to be validated with observations before applying the model for complex oceanographic process studies. The comparison of model simulations with observations from WHOI, DS1, DS3 and DS4 moored buoys shows that model is able to reproduce the seasonal evolution of temperature structure in the $\mathrm{AS}$ and BoB. The analysis showed that good quantitative as well as qualitative agreement exists between the anomalies of sea level observed from tide-gauges and T/P during 1993-2000 and those calculated from model. The correlation between model and $\mathrm{T} / \mathrm{P}$ is better in NIO and poor correlation is seen in the western $\mathrm{AS}$ and western $\mathrm{BoB}$. The key regions of interannual variability in the tropical Indian Ocean are southeast AS and eastern EIO, the correlations over theses regions are found to be larger than 0.8 with maxima in the southeastern AS. The NIO shows SST warming of about $0.4^{\circ} \mathrm{C}$ during $1958-2000$. The linear trend of thermocline heat content increase for the NIO is $0.0018 \times 10^{11} \mathrm{~J} / \mathrm{m}^{2}$ per year. In the NIO the model SLA shows a linear increasing trend of $0.31 \mathrm{~mm} /$ year over $1958-2000$. This is very close to the contribution of thermosteric term to the observed global average sea level rise. The model and $\mathrm{T} / \mathrm{P}$ observations show that the sea level rise over NIO is only about one third of global average sea level rise. The model temperature shows slight cooling in the subsurface $(\sim 400 \mathrm{~m})$. The subsurface cooling in the tropical Indian Ocean is further discussed by Alory et al (2007) and suggested that the cooling is due to the shallowing of thermocline transmitted from the Pacific Ocean by the throughflow, whereas Han et al (2006) linked the cooling to the local wind forcing and associated upward Ekman pumping velocity. But the model thermocline heat content shows the signature of subsurface cooling south of $5^{\circ} \mathrm{S}$, even without the inclusion of Indonesian throughflow in the model. This result implies that the thermodynamical processes responsible for the subsurface cooling need to be investigated further. Also the role of this subsurface cooling in the upper ocean warming requires further modeling studies. 


\section{Acknowledgements}

Bijoy acknowledges CSIR, India for providing financial support for research work. We also acknowledge financial support of INCOIS, Hyderabad. The support of Director, I.I.T.M. is also sincerely acknowledged. The authors acknowledge Dr. Stephen Griffies and Dr. P S Swathi for their support and discussions during the model installation and integration. We acknowledge Dr. Shankar and Dr. Unnikrishnan for scientific discussions and their suggestions to improve the paper. The comments from two anonymous reviewers helped us to improve the manuscript considerably. The T/P SSHA products were produced by SSALTO/DUACS and distributed by AVISO with support from CNES. Acknowledgments are also due to PSMSL, NCAR, UMD, and UK met office for various datasets used in the study and GFDL, Princeton for making the MOM4 code available. Figures are drawn using Ferret.

\section{References}

Alory G, Wijffels S and Meyers G 2007 Observed temperature trends in the Indian Ocean over 1960-1999 and associated mechanisms; Geophys. Res. Lett. 34 L02606 doi:10.1029/2006GL028044.

Antonov J I, Levitus S and Boyer T P 2002 Steric sea level variations during 1957-1994: Importance of salinity; J. Geophys. Res. 107 doi:10.1029/2001JC000964.

Bindoff N L, Willebrand J, Artale V, Cazenave A, Gregory J, Gulev S, Hanawa K, Le Quéré C, Levitus S, Nojiri Y, Shum C K, Talley L D and Unnikrishnan A 2007 Observations: Oceanic Climate Change and Sea Level; In: Climate Change 200\%: The Physical Science Basis. Contribution of Working Group I to the Fourth Assessment Report of the Intergovernmental Panel on Climate Change (eds) Solomon S, Qin D, Manning M, Chen Z, Marquis M, Averyt K B, Tignor $\mathrm{M}$ and Miller $\mathrm{H}$ L, Cambridge University Press, Cambridge, United Kingdom and New York, USA.

Bryan K and Lewis L J 1979 A water mass model of the world ocean; J. Geophys. Res. 84 2503-2517.

Carton J A, Giese B S and Grodsky S A 2005 Sea level rise and the warming of the oceans in the Simple Ocean Data Assimilation (SODA) ocean reanalysis; J. Geophys. Res. 110 C0900610.1029/2004JC002817.

Carton J A and Giese B S 2006 SODA: A reanalysis of ocean climate; Mon. Wea. Rev., accepted.

Chambers D P, Tapley B D and Stewart R H 1999 Anomalous warming in the Indian Ocean coincident with El Niño; J. Geophys. Res. 104 3035-3047.

Cheney R E, Miller L, Agreen R, Doyle N and Lillibridge J 1994 Topex/Poseidon: The 2-cm solution; J. Geophys. Res. 99 24,553-24,563.

Church J A, White N J, Coleman R, Lambeck K and Mitrovica J X 2004 Estimates of the regional distribution of sea-level rise over the 1950 to 2000 period; J. Climate 17 2609-2625.

Church J A, White N J and Hunter J R 2006 Sea-level rise at tropical Pacific and Indian Ocean islands; Global and Planetary Change 53 155-168.
Griffies S M, Harrison M J, Pacnowski R C and Rosati A 2003 A Technical Guide to MOM4; GFDL Ocean Group Technical Report No. 5, Princeton, NJ: NOAA/Geophysical Fluid Dynamics Laboratory.

Han W, Meehl G A and Hu A 2006 Interpretation of tropical thermocline cooling in the Indian and Pacific oceans during recent decades; Geophys. Res. Lett. 33 L23615 doi:10.1029/2006GL027982.

Large W G, McWilliams J C and Doney S C 1994 Oceanic vertical mixing: A review and a model with a nonlocal boundary layer parameterization; Reviews of Geophysics 32 363-403.

Large W G and Yeager S G 2004 Diurnal to decadal global forcing for ocean and sea-ice models: the data sets and flux climatologies; NCAR, Technical Note NCAR/TN460+STR, 111 pp.

Levitun S 1998 Climatological atlas of the world ocean; Tech. Rep., NOAA, Rockville, Md.

Levitus S, Antonov J and Boyer T P 2000 Warming of the world ocean; Science 287 2225-2229.

Levitus S, Antonov J L, Wang J, Delworth $\mathrm{T}$ L, Dixon K W and Broccoli A J 2001 Anthropogenic warming of Earth's climate system; Science 292 267-270.

Levitus S, Antonov J and Boyer T P 2005 Warming of the world ocean, 1955-2003; Geophys. Res. Lett. 32 doi:10.1029/2004GL021592.

McDougall T J, Jacket D R, Wright D G and Feistel R 2003 Accurate and computationally efficient algorithms for potential temperature and density of seawater; J. Atm. Ocean. Tech. 20 730-741.

Premkumar K, Ravichandran M, Kalsi S R, Sengupta D and Gadgil S 2000 First results from new observational system over the Indian Seas; Curr. Sci. $\mathbf{7 8}$ 323-330.

Rayner N A, Parker D E, Horton E B, Folland C K, Alexander L V, Rowell D P, Kent E C and Kaplan A 2003 Global analysis of sea surface temperature, sea ice, and night marine air temperature since the late nineteenth century; J. Geophys. Res. 108 doi:10.1029/2002JD002670.

Rossby C 1959 Current problems in meteorology; In: The Atmosphere and Sea in Motion; Rockefeller Inst. Press, New York, pp. 9-50.

Sengupta D and Ravichandran M 2001 Oscillations of Bay of Bengal sea surface temperature during the 1998 summer monsoon; Geophys. Res. Lett. 28 2033-2036.

Tapley B D, Chambers D P, Shum C K, Eanes R J and Ries J C 1994 Accuracy assessment of large scale dynamic topography from TOPEX/POSEIDON altimetry; J. Geophys. Res. 99 24,605-24,617.

Unnikrishnan A S, Kumar K R, Fernandes S E, Michael G S, and Patwardhan S K 2006 Sea level changes along the Indian coast: Observations and projections; Curr. Sci. 90 $362-368$.

Unnikrishnan A S and Shankar D 2007 Are sea-level-rise trends along the coasts of the north Indian Ocean consistent with global estimates?; Global and Planetary Change 57 301-307.

Vinayachandran P N, Saji N H and Yamagata T 1999 Response of the equatorial Indian Ocean to unusual wind event during 1994; Geophys. Res. Lett. 26 $1613-1616$.

Weller R A, Baumgartner M F, Josey S A, Fischer A S and Kindle J C 1998 Atmospheric forcing in the Arabian Sea during 1994-1995: observations and comparisons 
with climatology and models; Deep-Sea Res. Part II $\mathbf{4 5}$ 1961-1999.

Weller R A, Fischer A S, Rudnick D L, Eriksen C C, Dickey T D, Marra J, Fox C and Leben R 2002 Moored observations of upper-ocean response to the monsoons in the Arabian Sea during 1994-1995; Deep-Sea Res. Part II 49 2195-2230.

Woodworth P L and Player R 2003 The Permanent Service for Mean Sea Level: an update to the 21st century; J. Coastal Res. 19 287-295.

MS received 4 April 2007; revised 19 October 2007; accepted 23 October 2007 